\title{
Što je sve prošlo ispod radara - odgovor na polemički rad Dolenec i Širinić
}

\author{
ALEKSANDAR ŠTULHOFER \\ Odsjek za sociologiju, Filozofski fakultet Sveučilišta u Zagrebu \\ IVAN RIMAC \\ Pravni fakultet Sveučilišta u Zagrebu \\ VUK VUKOVIĆ \\ University of Oxford
}

Kolegice Danijela Dolenec i Daniela Širinić u nedavno su objavljenom radu Još uvijek teorijska fantazija: egalitarni sindrom Josipa Županova (Dolenec i Širinić, 2018) izložile sustavnu kritiku teorijskih pretpostavki i empirijskih rezultata naših pokušaja operacionalizacije (usp. Štulhofer i Burić, 2015; Burić i Štulhofer, 2016; Vuković, Štulhofer i Burić, 2017; Rimac, Burić i Štulhofer, 2017) i revitalizacije

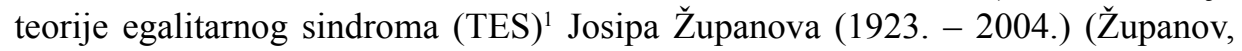
1970). U ovom kratkom osvrtu sažeto predstavljamo prigovore na teze i tumačenja koja nam se čine nedovoljno promišljenim ili problematičnim u tekstu Dolenec i Širinić. Kako bismo, u mjeri u kojoj je to izvedivo, zauzdali subjektivnost, nastojali smo čitati njihov rad kao recenzenti, dakle onako kao što su ga, pretpostavljamo, čitali anonimni recenzenti časopisa u kojem je objavljen. ${ }^{2}$ Da su upozorili autorice na niže navedena mjesta, njihov bi rad, vjerujemo, imao veću težinu - osobito za one za koje egalitarni sindrom nije primarno ideološko pitanje.

Krećemo od onoga u čemu recenzenti nisu pogriješili. Rad kolegica Dolenec i Širinić važan je prilog diskusiji o relevantnosti bavljenja egalitarnim sindromom.

${ }^{1}$ U nastavku teksta, kao i u citatima iz Dolenec i Širinić (2018), za teoriju egalitarnog sindroma koristimo kraticu TES.

${ }^{2} \mathrm{~S}$ obzirom na to da je rukopis objavljen kao izvorni znanstveni rad, a ne pismo uredniku ili polemički odgovor, nužno je prošao postupak recenzije. 
Uz to što se u tekstu prepoznaje velik uloženi trud, riječ je o jednom od rijetkih radova u domaćim društvenim znanostima koji otvaraju kritički dijalog među znanstvenicima. Razloge zbog kojih vlada deficit takvih radova vjerojatno treba tražiti u našoj tradiciji nezamjeranja, ograničenoj veličini akademske zajednice, a sigurno i u tome što je često nemoguće doći do originalnih podataka na kojima su nastale analize koje smatramo upitnima. Sve to čini naše zamišljeno recenzentsko čitanje rada kolegica Dolenec i Širinić odgovornijim, ali i zahvalnijim zadatkom.

U nastavku komentiramo najproblematičnija mjesta u navedenome radu.

(1) Na stranici 15 autorice pišu: “... Štulhofer i Burić $(2015,2016)$, poduzimajući empirijsku verifikaciju TES-a gotovo pedeset godina nakon njezinog nastanka, ne aktualiziraju ga unutar suvremenih međunarodnih i domaćih istraživanja u modernizacijskoj teoriji." Premda je moguće smatrati kako bi svaki empirijski rad trebao uključivati široki konceptualni okvir - što je, po našem sudu, pogrešan znanstveni pristup kada je riječ o empirijskim istraživanjima - nejasno je zašto bi valjanost operacionalizacije egalitarnog sindroma trebala počivati na njegovom smještanju unutar srodnih teorijskih modela? Također, autorice zanemaruju nedavni Burićev rad koji nudi upravo takvu kontekstualizaciju (usp. Burić, 2017). S obzirom da ga citiraju kao da je napisan na engleskom jeziku (što nije), nije jasno jesu li ga autorice uopće pročitale.

(2) Na stranici 17 autorice iznose sljedeću zamjerku: “... Ostaje otvoreno pitanje zašto se Štulhofer i Burić nisu koristili mjerama koje Inglehart razvija i unapređuje već desetljećima. O obrascima individualnih vrijednosnih orijentacija u Hrvatskoj sigurno možemo mnogo više naučiti primjenom međunarodno validiranih mjera nego izradom vlastitih instrumenata koje implementiramo samo u Hrvatskoj." Premda i sami gajimo simpatije prema Inglehartovoj teoriji postmaterijalističkih vrijednosti, nejasno je na temelju čega autorice smatraju da se operacionalizacija Županovljeve TES (kojoj je, ne tako davno, Dolenec zamjerila empirijsku neutemeljenost; Dolenec, 2014) može izvesti uporabom postojećih mjera, kao što je, primjerice, Inglehartova i Welzelova mjera tradicionalnosti/sekularnosti? Čuđenje samo raste kada tek nekoliko rečenica dalje autorice same zaključuju da u Inglehartovoj i Welzelovoj operacionalizaciji "nema nijedne čestice koja mjeri nešto što bi bilo slično bilo kojoj komponenti egalitarnog sindroma”. Kritizirati egalitarni sindrom i njegovu operacionalizaciju pozivajući se na nešto što nema veze sa Županovljevom idejom jednako je besmisleno kao i smatrati da je, ako je Županov u pravu, Inglehart nužno u krivu.

(3) Na stranici 22, slijedeći mjeru individualne percepcije pravednosti distribucije dohodaka koju je razvila Simone Schneider, autorice koriste ISSP (International Social Survey Programme) bazu podataka kako bi demonstrirale da su hrvatski sudionici istraživanja "prosječno egalitarno orijentirani". No, problem je u tome što 
indeks ne polazi od standardiziranog omjera između dohotka radnika i direktora, pa će jednu te istu vrijednost na indeksu, primjerice 0 , imati sve zemlje koje obilježava potpuno poklapanje između percipiranog i željenog omjera direktorske i radničke plaće, bio on 2:1 ili 22:1. Prosječni rezultat Hrvatske ne govori, stoga, o stupnju egalitarnosti, kao što autorice tvrde, već samo o prosječnom legitimiranju specifičnih (za svaku zemlju drukčijih) razlika u plaćama.

Te specifičnosti jasno se odražavaju u prikazanom poretku zemalja (usp. grafikon 1 na str. 23, na kojem nije jasno je li apscisa logaritmirana). Veće vrijednosti indeksa imaju uglavnom tranzicijske zemlje, u kojima je stvarni raspon plaća naglo porastao (usp. Rusiju) te zemlje s vrlo izraženim socijalnim politikama. Nasuprot tome, na dnu ljestvice, s minimalnom željom za promjenom, nalazimo zemlje s vrlo izraženim razlikama između bogatih i siromašnih (Argentina i Južnoafrička Republika), ali i one koje su dugogodišnjim socijalnim oporezivanjem dobiti umanjile potrebu za uravnilovkom plaća (skandinavske zemlje). Kada bi grafikon doista prikazivao stupanj egalitarnosti, Nijemci bi bili drastično skloniji egalitarizmu od Ciprana, kao i Rusi od Bugara. Vjeruju li, doista, autorice u to?

No, još su dvije stvari tu problematične. Prvo, egalitarni sindrom je višedimenzionalni konstrukt (teorijski i empirijski), što znači da ga ne možemo mjeriti česticom koja, u najboljem slučaju, reprezentira samo jednu dimenziju. U suprotnome, s obzirom na razine percepcije poduzetništva te poduzetničke aktivnosti (Singer, Šarlija, Pfeifer i Oberman Peterka, 2019), moglo bi se tvrditi kako je Hrvatska značajno egalitarnija od većine drugih europskih zemalja (kao i slično razvijenih svjetskih zemalja). Naravno, takav pars pro toto bio bi posve pogrešan.

Druga je poteškoća u tome što Dolenec i Širinić, čini se, smatraju kako je moguće uspoređivati razine egalitarizma u različitim zemljama bez prethodno validiranog višedimenzionalnog instrumenta te što apriori odbacuju mogućnost kulturne specifičnosti egalitarnog sindroma. Bez testiranja kroskulturne invarijantnosti višedimenzionalne mjere egalitarnog sindroma nije moguće odbaciti, primjerice, tezu o njegovoj regionalnoj specifičnosti.

(4) Na 24. stranici autorice navode sljedeće: “... Štulhofer i Burić $(2015,2016)$ također ne raspravljaju o izboru primjerenih metoda istraživanja, kao ni o tome što se izborom metode anketnog upitnika dobiva ili gubi." Nekoliko stranica dalje nastavljaju: “... da bismo ovim (Županovljevim, op. A. Š.) tezama dali empirijsku potkrepu, potrebne su nam analize dinamike među elitama, studije razvoja ekonomskih i političkih institucija, analize političkih rascjepa i dinamike izbornog natjecanja u Hrvatskoj. Anketnim upitnikom kao jedinom metodom istraživanja TES se ne može empirijski potvrditi. Može se samo, uz uvjet da je mjerni instrument valjan, utvrditi prisutnost određenih vrijednosti u populaciji i tako zahvatiti jedan njezin aspekt." Nejasno je koji bi to bili drugi aspekti, ako su naši ciljevi bili operacionalizacija 
TES te utvrđivanje raširenosti egalitarnog sindroma u općoj populaciji? Pomalo je trivijalno ponavljati kako je ispitivanje na probabilističkom uzorku opće populacije najprimjerenija metoda za ispitivanje dominantnih društvenih vrijednosti, no možda je nužno za shvaćanje da je ambiciozan (i vjerojatno neprovediv) istraživački program koji autorice predlažu ne samo nepotreban već i neadekvatan - barem kada je riječ o ciljevima radova koje autorice apostrofiraju.

(5) Na stranicama 28 i 29 pišu o razlikama između nadređenih i skupnih konfirmacijskih faktorskih modela, opisujući određene razlike. Premda vizualni prikaz potvrđuje da je naš model nadređeni, odnosno model višeg faktorskog reda (Štulhofer i Burić, 2015; Burić i Štulhofer, 2016), autorice zamjeraju što to nije eksplicitno pojašnjeno te argumentirano boljim pristajanjem takvog modela u odnosu na skupni ("Samo ako konstrukt višeg reda ima veću eksplanatornu snagu od njegovih zasebnih dimenzija odnosno, pojednostavnjeno, ako su istraživači pokazali da novi koncept donosi više od pukog zbroja svojih komponenata, prihvaća se kompleksniji višerazinski model”, str. 30). Formalno gledano, autorice su u pravu, no činjenica da Županov eksplicitno pretpostavlja povezanosti među dimenzijama nižeg reda (Županov, 1970) traži nadređenu, a ne skupnu specifikaciju konfirmacijskog faktorskog modela. Sindrom je latentna dimenzija višeg reda definirana kompleksnim simptomima (latentne dimenzije nižeg reda). Naš izbor, dakle, počiva na jasnom teorijskom očekivanju.

(6) Na stranici 30 autorice kritiziraju činjenicu da invarijantnost modela s obzirom na spol i dob nismo ispitali i na mjernoj te skalarnoj razini (već samo na konfiguralnoj; Burić i Štulhofer, 2016). Prigovor stoji, no ne invalidira mjerni instrument. S jedne strane, razmišljanje o razini invarijatnosti potrebnoj za robusne analize u odvojenim skupinama nužno treba uzeti u obzir složenost višedimenzionalne i višerazinske mjere koja indicira egalitarni sindrom. S druge strane, autorice testiraju invarijatnost modela koristeći pet (usp. Dolenec i Širinić, 2018: 35-36), a ne dvije dobne skupine koje su sučeljene u originalnom radu. Štoviše, autorice iz analize izbacuju jednu od naših dviju skupina. Vjerojatno je nepotrebno tumačiti kako povećavanjem broja skupina koje se uspoređuju raste i vjerojatnost da se model neće ponašati jednako u svim skupinama. Ako su, dakle, autorice željele pokazati da naša tvrdnja o invarijatnosti modela u dvjema specifičnim dobnim skupinama ne drži vodu, onda su više razine invarijatnosti trebale testirati na istim skupinama, ne ulazeći u (ovdje nepotrebnu) teorijsku debatu o procesu socijalizacije.

(7) Na stranici 32 autorice pišu: "Problemi s malim brojem ispitanika u županijama, odnosno slučajeva na individualnoj razini, te malim brojem županija, odnosno slučajeva na makrorazini, dovode u pitanje i analizu povezanosti. Prvo, prikazana analiza koja u obzir uzima raspone prosječnih vrijednosti prihvaćanja 
egalitarnog sindroma po županijama pokazuje da nema dovoljno varijabilnosti na zavisnoj varijabli koju bismo mogli testirati za povezanost s faktorima koje smatramo bitnima za njezino objašnjenje. Drugo, čak i da taj problem zanemarimo i vodimo se rezultatima o povezanosti prosječne vrijednosti SEMA-27 i županijskog bruto domaćeg proizvoda, koje Burić i Štulhofer navode, autori izvještavaju o Pearsonovom korelacijskom koeficijentu od $-0,27$, odnosno $-0,11$ bez grada Zagreba. Riječ je o slaboj povezanosti koja, prema standardima u društvenim znanostima, nije uvjerljiva. Primjerice, kada spominju ograničenja analize koja proizlaze iz malog broja slučajeva uključenih u analizu (21 županija), Rimac, Burić i Štulhofer (2017) navode kako je Robert Putnam (Putnam i dr., 2003) svoju analizu o dinamici društvenog kapitala u Italiji temeljio na 20 regija, dakle također malom broju slučajeva. No, pritom ne spominju da se Putnam, nasuprot njima, oslanjao na niz raznovrsnih podataka i istraživačkih metoda te da je uključio različite razine analize. Isto tako ne spominju da su Putnamove korelacijske analize, prikazane uz uvjerljive grafikone raspršenosti, rezultirale izrazito visokim korelacijskim koeficijentima u rasponu stupnja povezanosti od 0,7 do 0,9 ." U ovom podužem citatu kriju se tri problema. Prvi po redu jest tvrdnja kako na županijskoj razini indikator egalitarnog sindroma nema dovoljnu varijabilnost. Nije posve jasno kako su autorice došle do takvog zaključka, no čini se da bi to mogla biti posljedica skoka s konstatacije o ograničenoj mogućnosti rangiranja županija prema raširenosti egalitarnog sindroma na zaključivanje o rezultatima korelacijskih i regresijskih analiza. Pitanje je li varijabilnost "dovoljna" ultimativno je empirijsko pitanje: ako postoje značajne povezanosti s drugim konstruktima, onda je postojeća varijabilnost "dovoljna". U svakom slučaju, utjecaj podcijenjene varijabilnosti županijskih razina egalitarnog sindroma na povezanosti iznesene u radovima Burić i Štulhofer (2016) te Vuković i sur. (2017) nužno je restriktivan, odnosno ne ide u korist argumentaciji teze o perzistenciji egalitarnog sindroma. Drugi problem odnosi se na tezu da povezanosti u rasponu od 0,11 do 0,27 nisu "uvjerljive" u društvenim znanostima. Nije jasno na koje se "standarde" autorice pozivaju, no ako time žele reći da je praktična važnost tih korelacija zanemariva, onda je njihovo razumijevanje znanosti prilično osebujno. Posljednji problem odnosi se na implikaciju kako je u redu koristiti mali broj jedinica višeg reda ako ste dobili snažne $\left(0,70-0,90\right.$; Putnam, 1993), ${ }^{3}$ no ne i umjerene povezanosti između zavisne i nezavisnih varijabli u regresijskom modelu (0,34-0,40; Vuković, Štulhofer i Burić, 2017). Autorice pritom, čini se, gube iz vida kako su i u radovima koje kritiziraju korištene raznorodne vrste podataka, uključujući i povijesne. Pitam se bi li na nastavi metodologije studentima savjetovale nešto poput: "Ponekad je u

3 Valja podsjetiti kako je Putnam (1993: 155) koristio običnu linearnu regresiju, za razliku od našeg, bitno robusnijeg višerazinskog regresijskog modeliranja koje istodobno procjenjuje i individualni i nadređeni grupni varijabilitet. 
redu koristiti upitnu statističku proceduru, ali samo ako ste dobili uvjerljive rezultate"?

Nije naodmet ovdje ponoviti kako su upozorenja o nereprezentativnosti korištenog populacijskog uzorka na županijskoj razini te ograničenoj statističkoj snazi županijskih analiza jasno navedena u sva tri relevantna rada (Burić i Štulhofer, 2016; Vuković, Štulhofer i Burić, 2017; te Rimac, Burić i Štulhofer, 2017).

(8) Na stranici 32 autorice sugeriraju kako bi neki od rezultata objavljenih u Vuković i sur. (2017) te Rimac i sur. (2017) mogli biti lažno pozitivni, pri čemu se pozivaju na literaturu o problemima višerazinskog regresijskog modeliranja s malim brojem jedinica više razine (u našem slučaju, županije). Dolenec i Širinić tako pišu: "Dapače, korištenje višerazinske regresijske analize na 21 županiji i s malim grupama ispitanika ${ }^{4}$ na individualnoj razini u naprednijim modelima rezultira umjetnom redukcijom standardnih pogrešaka i neizbježno dovodi do lažnih pozitivnih nalaza (Maas i Hox, 2005; Stegmueller, 2013).” Dovodi li, neizbježno, do lažno pozitivnih nalaza? Da su autorice pažljivije pročitale prvi od dva rada koji citiraju, ustanovile bi da takve analize podcjenjuju standardne pogreške, no ne rezultiraju pristranim regresijskim koeficijentima (Maas i Hox, 2005: 89 i 90). Kao što Maas i Hox pokazuju, regresijski koeficijenti - dobiveni u našim radovima (Vuković, Štulhofer i Burić, 2017; Rimac, Burić i Štulhofer, 2017) - u najgorem su slučaju pristrani na prosječnoj razini $<0,05 \%$. Kada je riječ o lažno pozitivnim nalazima, treba imati u vidu da su naše analize populacijske (jer uključuju sve županije), pa je time testiranje značajnosti, koje je važno kako bi se (ako su određeni uvjeti zadovoljeni) iz uzorka nešto moglo zaključiti o populaciji, ovdje posve irelevantno

${ }^{4}$ U statistici nema "umjetne redukcije statističkih pogrešaka". Postoje statistički testovi veće ili manje statističke snage. Statistički testovi veće statističke snage mogu, sasvim opravdano, doći do zaključaka o postojanju razlika ili značajnosti korelacija na podacima na kojima statistički testovi manje snage ostaju pri zaključku da razlika nema.

Upravo u tom pogledu autorice griješe kada analizu pojedinih pogrešaka poduzorka pretpostavljaju statističkim zaključcima proizašlim iz analize varijance ili višerazinske analize. Takvi testovi ne izvode zaključak uzimajući u jednakoj mjeri podatke iz poduzoraka s malim brojem ispitanika i velikom pogreškom uzorka i poduzoraka s većim brojem ispitanika i manjim pogreškama uzorka, nego se veća važnost daje većim skupovima podataka. Drugim riječima, da smo iz analize izbacili Ličko-senjsku županiju, rezultati se višerazinskog regresijskog modeliranja ne bi promijenili zbog toga što statistički postupak daje minimalno značenje najmanjem poduzorku. Za razliku od toga, izbacivanje Zagreba kao najvećeg poduzorka narušilo bi mogućnost dobivanja značajnih rezultata, a time i valjano zaključivanje. Upravo provođenjem analize na podacima bez najvećeg poduzorka (Zagreb) željeli smo postaviti najnižu empirijsku procjenu efekta koji smo provjeravali (najveća pogreška tipa II). Ako se, dakle, nešto može problematizirati u našoj analizi, to je pitanje u kojoj su mjeri zaključci o cijelom skupu podataka zasnovani na dihotomiji Zagreb vs. ostale županije, a nikako pitanje je li Ličko-senjska županija imala premalo ispitanika. 
(usp. Burić i Štulhofer, 2016; Rimac, Burić i Štulhofer, 2017). U prvome od dva navedena rada p-vrijednosti nisu ni navedene u tablici 2 (usp. str. 13), upravo zbog karaktera analize.

U zamišljenoj ulozi recenzenta, za većinu gore navedenih dijelova rukopisa predložili bismo izbacivanje, a za preostale temeljitu doradu. Time ne želimo reći da Dolenec i Šarinić nisu uočile određene nedorečenosti u operacionalizaciji te ograničenja u validaciji mjere egalitarnog sindroma, od kojih smo većinu transparentno iznijeli u objavljenim radovima. Ograničenja su sastavni dio znanstvenog rada, koja nerijetko bolje prepoznajemo u tuđim nego u vlastitim radovima. Ono u čemu se mišljenje i zaključci autorica razlikuju od naših jest odgovor na pitanje o dosegu tih ograničenja. Jesu li stvarna ograničenja radova Štulhofera i suradnika dovoljna za odbacivanje predložene mjere egalitarnog sindroma i rezultata njezine dosadašnje primjene?

Iz naše perspektive, dosadašnja priča o egalitarnom sindromu može se sažeti na sljedeći način: (a) Županovljeva TES jedna je od malobrojnih originalnih teorija razvijenih u domaćim društvenim znanostima; (b) uzmemo li u sve dosadašnje nalaze $u$ obzir, nedavno predložena 5-dimenzionalna mjera egalitarnog sindroma čini se valjanom (premda ne nužno i konačnom) operacionalizacijom TES; (c) prethodnu tezu podupiru rezultati povijesne analize koja, premda ograničenog dosega, sugerira kako su i ruralno naslijeđe i reakcija na tranzicijske troškove generatori egalitarnog sindroma u suvremenom hrvatskom društvu (Vuković, Štulhofer i Burić, 2017); te (d) inicijalne analize u skladu su sa Županovljevom tvrdnjom kako je egalitarni sindrom negativno povezan sa socioekonomskim razvojem (Burić i Štulhofer, 2016). Kao istraživači navodno skloni "suhom prikazu statističkih podataka" i "golom empiricizmu", ne možemo isključiti mogućnost da će buduća istraživanja demantirati naše zaključke. Nijedno empirijsko istraživanje nije konačni dokaz neke teorije, već tek korak prema odgovoru na pitanje koliko ona dobro opisuje stvarnost. Stoga očekujemo kako će budući radovi ponuditi dodatne i, nadamo se, kvalitetnije empirijske uvide o fenomenologiji egalitarnog sindroma te pomoći u razmišljanjima kako ga ublažiti.

\section{LITERATURA}

Burić, Ivan. 2017. Teorijske refleksije o mogućim uzrocima inertnosti egalitarnog sindroma. Revija za sociologiju, (47), 3: 335-359.

Burić, Ivan i Štulhofer, Aleksandar. 2016. In search of the egalitarian syndrome: cultural inertia in Croatia? Financial Theory and Practice, (40), 4: 361-382. 
Dolenec, Danijela. 2014. Preispitivanje "egalitarnog sindroma” Josipa Županova. Politička misao, (51), 4: 41-64.

Dolenec, Danijela i Širinić, Daniela. 2018. Još uvijek teorijska fantazija: egalitarni sindrom Josipa Županova. Politička misao, (55), 3: 7-42.

Maas, Cora J. M. i Hox, Joop J. 2005. Sufficient sample sizes for multilevel modeling. Methodology, (1), 3: 86-92.

Putnick, Diane L. i Bornstein, Marc H. 2016. Measurement invariance conventions and reporting: The state of the art and future directions for psychological research. Developmental Review, (41), 71-90.

Putnam, Robert. 2003. Making Democracy Work: Civic Traditions in Modern Italy. Princeton University Press. Princeton, N.J.

Rimac, Ivan, Burić, Ivan i Štulhofer, Aleksandar. 2017. Višerazinsko modeliranje egalitarnog sindroma i validacija kratke skale SEMA-5. Politička misao, (54), 3: 64-79.

Singer, Slavica, Šarlija, Nataša, Pfeifer, Sanja i Oberman Peterka, Sunčica. 2019. Što čini Hrvatsku (ne) poduzetničkom zemljom? GEM Hrvatska 2018. CEPOR. Zagreb.

Štulhofer, Aleksandar i Burić, Ivan. 2015. Je li egalitarni sindrom samo teorijska fantazija? Empirijski hommage Josipu Županovu. Politička misao, (52), 3: 7-31.

Vuković, Vuk, Štulhofer, Aleksandar i Burić, Ivan. 2017. Je li Županov imao pravo? Testiranje podrijetla i perzistencije egalitarnog sindroma. Društvena istraživanja, (26), 2: 207-225.

Županov, Josip. 1970. Egalitarizam i industrijalizam. Naše teme, (14), 2: 237-296. 